\title{
The Evaluation of Retinol, $\alpha$-Tocopherol, Cholecalciferol and Reproductive Hormones Levels After Administrated Allium Schoenoprasum L. Ethanol Extract and Acrylamide in the Female Rats
}

\author{
Saadet Belhan ${ }^{1, a, *}$, Zübeyir Huyut ${ }^{2, b}$, İbrahim Hakkı Yörük ${ }^{3, c}$, Semih Yaşara, \\ Leyla Mis ${ }^{5, e}$, Adnan Ayan ${ }^{6, f}$ \\ ${ }^{1}$ Department of Reproduction and Artificial Insemination, Faculty of Veterinary Medicine, Van Yuzuncu Yll University, 65080 Van, Turkey \\ ${ }^{2}$ Department of Biochemistry, Faculty of Medicine, Van Yuzuncu Yll University, 65080 Van, Turkey \\ ${ }^{3}$ Department of Chemistry, Faculty of Sciences, Van Yuzuncu Yll University, 65080 Van, Turkey \\ ${ }^{4}$ Department of Medical Laboratory Technics, Ozalp Vocational High School, Van Yuzuncu Yll University, 65080 Van, Turkey \\ ${ }^{5}$ Department of Physiology, Faculty of Veterinary Medicine, Van Yuzuncu Yll University, 65080 Van, Turkey \\ ${ }^{6}$ Department of Genetics, Faculty of Veterinary Medicine, Van Yuzuncu Yll University, 65080 Van, Turkey \\ *Corresponding author
}

A R T I C L E I N F O A B S T R A C T

Research Article

This study was carried out to determine the levels of retinol, $\alpha$-tocopherol, cholecalciferol and reproductive hormones (follicle stimulating hormone - FSH, luteinizing hormone - LH, progesterone, estradiol) in the female rats administrated Allium schoenoprasum L. ethanol extract (ASLEE) and acrylamide. The study was performed on thirty-two Wistar albino female rats (200-

Received : $18 / 06 / 2020$ Accepted : 04/07/2020 220 grams). The rats were divided into 4 groups with an equal number. Serum LH values were higher in the ASLEE group compared to the other groups. Control group: No treatment was performed. Acrylamide group: Acrylamide was administrated by gastric gavage at a dose of $25 \mathrm{mg}$ / kg daily. ASLEE group: ASLEE was administrated by gastric gavage at a dose of $200 \mathrm{mg} / \mathrm{kg}$ daily. Acrylamide + ASLEE group: Acrylamide was administrated by gastric gavage at a dose of $25 \mathrm{mg} / \mathrm{kg}$ daily. Then ASLEE was administered by gastric gavage at a dose of $200 \mathrm{mg} / \mathrm{kg}$ per

Keywords: Acrylamide Allium Schoenoprasum L Rat Reproductive Hormones Vitamins day. Serum FSH and LH values were significantly lower in the acrylamide group compared to the other groups. Serum LH values in the acrylamide + ASLEE group were significantly restored compared to the acrylamide group. Serum estradiol values were partially lower in the acrylamide group compared to other groups, but there was no significant difference between the groups. Serum progesterone values in the acrylamide group were significantly lower than the control group. Serum progesterone values were higher in the acrylamide + ASLEE group compared to the acrylamide group. As a result, the levels of retinol, $\alpha$-tocopherol, cholecalciferol and reproductive hormones in ASLEE were determined in this study. In addition, when ASLEE was applied with acrylamide, the rate of change in the relevant parameters was determined.

\section{saadetkaratas@hotmail.com ibrahimyoruk66@hotmail.com leylaaslan23@hotmail.com}
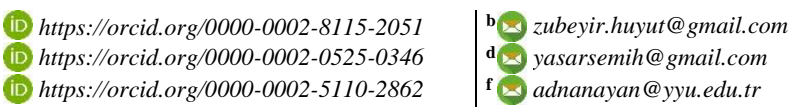

(iD) https://orcid.org/0000-0002-7623-1492 (iD) https://orcid.org/0000-0002-6564-3416

\section{Introduction}

Acrylamide is a colourless, odourless substance found in solid state in nature (Friedman et al., 2003). Acrylamide, which penetrates into the blood through the digestive tract or via the skin, is known to be carcinogenic or neurotoxic. Acrylamide is formed by exposure of carbohydrate-rich foods to temperatures exceeding $120^{\circ} \mathrm{C}$ (Rommens et al., 2008). Ready-made foods such as crackers, toast and chips are reported to form acrylamide due to the way they are produced (Viklund et al., 2008). Wei et al. (2014) reported that acrylamide $(20 \mathrm{mg} / \mathrm{kg}$ and $40 \mathrm{mg} / \mathrm{kg}$ ) administered to prepubertal female rats for 30 days caused decreases in body and organ (ovary and uterus) weights and also reduced the number of corpus luteum. In another study, it was reported that male rats receiving oral acrylamide for 8 weeks had decreased body weight and epididymal sperm reservoirs (Wang et al., 2010).

The vast majority of natural sources have been reported to have biological activities (Sevindik et al., 2017; Mushtaq et al., 2020; Mohammed et al., 2020; Sevindik, 2020). Allium schoenoprasum L. (Sirmo), a member of the family 
Lilyceae, is known as the chives (Parvu et al. 2014). Allium schoenoprasum L. has been reported to have antitumoral (Shirshova et al., 2014), antidiabetic, antioxidant effects (Çelik et al., 2008, Zeng et al., 2017). Allium schoenoprasum L. (Sirmo) ethanol extract has been reported to exert neuroprotective effects in mice by enhancing antioxidant defense against ischemia reperfusion injury (Singh et al., 2018).

This study was performed to evaluate the reproductive hormones (follicle stimulating hormone - FSH, luteinizing hormone - LH, progesterone, estradiol) and some vitamin (retinol, $\alpha$-tocopherol, cholecalciferol) levels in female rats administrated Allium schoenoprasum L. (Sirmo) ethanol extract and acrylamide.

\section{Materials and Methods}

\section{Animals}

The study was approved by the Van Yuzuncu Yil University Animal Experiments Local Ethics Committee (Approval No: 2020/01). Ethical rules were taken into consideration in all applications. Thirty-two female Wistar albino rats (200-220 grams) were used in the study. The rats were housed under standard laboratory conditions (12 hours light / 12 hours dark). There was no restriction on feed and water.

\section{Chemicals}

Acrylamide (Sigma for electrophoresis, $\geq 99 \%$, CAS No 76-06-1) were purchased from a pharmacy.

\section{Preparation of Plant Extract}

Allium schoenoprasum L. was collected in May and then dried in the shade. $300 \mathrm{~g}$ of A. schoenopraum was then ground in an electric mill and pulverized. It was then suspended in 4 liters of $80 \%$ ethanol for 3 days and passed through Watman filter paper and evaporated in a rotary evaporator at $50^{\circ} \mathrm{C}$ with ethanol (Koçak et al., 2019).

\section{Experimental Design}

The study lasted 15 days. Rats were divided into 4 groups.

- Control group $(n=8)$ : No treatment was performed.

- Acrylamide group $(n=8)$ : Acrylamide was given by gastric gavage at a dose of $25 \mathrm{mg} / \mathrm{kg}$ daily (Altinoz and Turkoz, 2014).

- A Allium schoenoprasum L. (Sirmo) group $(\mathrm{n}=8)$ : Allium schoenoprasum L. (Sirmo) ethanol extract was given by gastric gavage at a dose of $200 \mathrm{mg} / \mathrm{kg}$ daily (Aamir et al., 2016).

- Acrylamide + Allium schoenoprasum L. (Sirmo) group $(\mathrm{n}=8)$ : Acrylamide was given by gastric gavage at a dose of $25 \mathrm{mg} / \mathrm{kg}$ daily. Then Allium schoenoprasum L. (Sirmo) ethanol extract was administered by gastric gavage at a dose of $200 \mathrm{mg} / \mathrm{kg}$ per day.

At the end of the study, rats were sacrificed by high blood collection. Blood samples were taken into biochemistry tubes.

\section{Hormonal Analysis}

Serum estradiol, FSH, LH and progesterone measurements were performed on the Aboott Architect İ16200TM using chemiluminescence microparticle immunological method using the appropriate calibrator, control and kit. Serum estradiol levels were expressed as $\mathrm{pg} / \mathrm{mL}, \mathrm{FSH}$ and LH levels were expressed as $\mathrm{mlU} / \mathrm{mL}$ and progesterone levels were expressed as $\mathrm{ng} / \mathrm{mL}$.

\section{Plasma Extraction}

For the analysis of retinol, $\alpha$-tocopherol, cholecalciferol, $200 \mu \mathrm{L}$ plasma was taken into plastic tubes. $200 \mu \mathrm{L}$ of ethanol was added and vortexed for $1 \mathrm{mi}$. Then, it was centrifuged at 2000 RPM for 10 minutes. 800 $\mu \mathrm{L}$ of the resulting hexane phase were taken and dried under nitrogen gas. The residue was dissolved in $100 \mu \mathrm{L}$ of methanol and injected into the HPLC column (Miller and Yang, 1985; Zaspel and Csallany, 1983).

\section{Liquid Chromatography}

First, the instrument was prepared for analysis using retinol, $\alpha$-tocopherol, cholecalciferol standards. Then 100 $\mu \mathrm{L}$ of the extracts were injected into the liquid chromatography column. Diagnosis of retinol, $\alpha$ tocopherol, cholecalciferol was made using diode-array detector at 325, 265 and $290 \mathrm{~nm}$ wavelengths. Methenolwater (98: 2) was used as the mobile phase at a flow rate of $1.5 \mathrm{~mL} / \mathrm{min}$. The $\mathrm{C} 18$ column $(4.6 \mathrm{~mm} \times 25 \mathrm{~cm})$ was used for the separation of vitamins (Miller and Yang, 1985; Zaspel and Csallany, 1983; Reynolds and Judd, 1984). Analyses were performed with Agilent 1100 series HPLC instrument.

Statistical analysis: SPSS (version 20) was used for analysis. For the differences between the groups, Kruskalwallis, one of the non-parametric analysis methods, was preferred $(\mathrm{P}<0.05)$. OneWay ANOVA was used to determine which group caused the difference. Then, posthock multiple comparison test (Tukey HSD) was used. Means with a $\mathrm{P}$ value of 0.05 or less were considered significant compared to each other.

\section{Results}

Serum LH levels were higher in ASLEE group compared to all groups $(\mathrm{P}<0.001)$. However, serum LH levels decreased dramatically in the acrylamide group compared to the other groups $(\mathrm{P}<0.001)$. Serum LH levels were significantly restored in the acrylamide + ASLEE group compared to the acrylamide group $(\mathrm{P}<0.001)$.

When the serum FSH values were examined, the serum FSH values of the acrylamide group were lower than the other groups $(\mathrm{P}<0.020)$, but there was no significant difference between the serum FSH values of the other groups $(\mathrm{P}>0.05)$. In addition, serum estradiol levels were slightly lower in the acrylamide administrated groups compared to the other groups, but there was no significant difference between the groups $(\mathrm{P}>0.05)$. 
Table 1. Reproductive hormone values of all groups.

\begin{tabular}{l|cccc}
\hline \multicolumn{1}{c|}{ Parameters } & LH $(\mathrm{mlU} / \mathrm{L})$ & FSH $(\mathrm{mlU} / \mathrm{L})$ & Estradiol $(\mathrm{pg} / \mathrm{mL})$ & Progesterone $(\mathrm{ng} / \mathrm{mL})$ \\
\hline Control & $8.50 \pm 0.55$ & $47.17 \pm 7.19$ & $29.83 \pm 5.74$ & $63.27 \pm 2.66$ \\
Acrylamide & $3.84 \pm 0.45^{*}$ & $39.17 \pm 4.22^{\neq}$ & $26.41 \pm 2.23$ & $49.50 \pm 2.64^{*}$ \\
ASLEE & $10.16 \pm 0.46^{*}$ & $49.17 \pm 1.17$ & $29.69 \pm 1.44$ & $62.17 \pm 2.10$ \\
Acrylamide+ASLEE & $7.79 \pm 0.32$ & $43.67 \pm 4.93$ & $27.17 \pm 1.72$ & $54.48 \pm 2.64^{*}$ \\
P values & 0.001 & 0.020 & 0.072 & 0.001 \\
\hline
\end{tabular}

*P: Significant compared to other groups $(\mathrm{P}=0.001), \neq \mathrm{P}$ : Significant compared to control and ASLEE groups $(\mathrm{P}=0.020)$. LH: luteinizing hormone (mlU/L), FSH: follicle stimulating hormone (mlU/L), estradiol $(\mathrm{pg} / \mathrm{mL})$, progesterone $(\mathrm{ng} / \mathrm{mL})$.

When the condition was examined in terms of progesterone results, a situation similar to $\mathrm{LH}$ values appeared. Serum progesterone levels were significantly lower in the acrylamide administrated groups compared to the control group $(\mathrm{P}<0.001)$. Serum progesterone levels were higher in the acrylamide + ASLEE group compared to the acrylamide group and approached the control group values $(\mathrm{P}<0.001)$. The results are detailed in Table 1 .

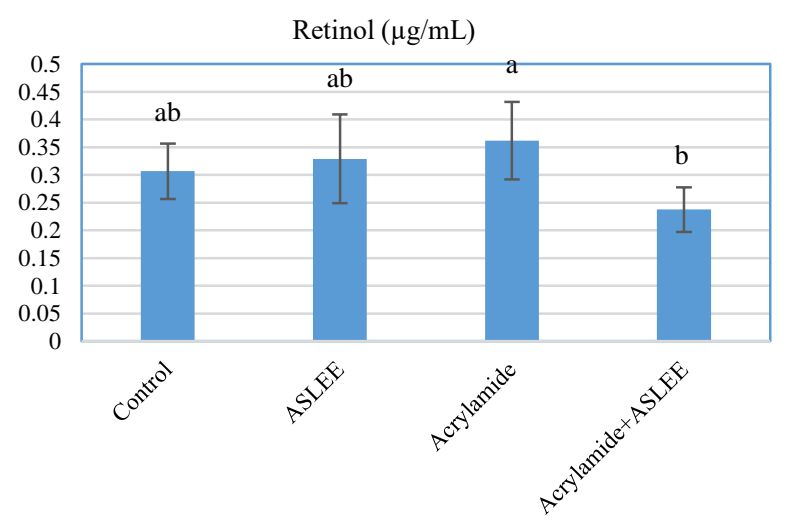

Figure 1. Comparison of retinol values between groups

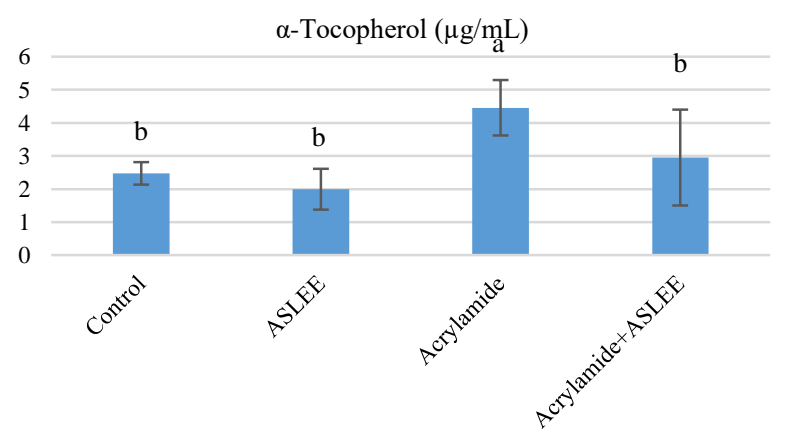

Figure 2. Comparison of $\alpha$-tocopherol values between groups

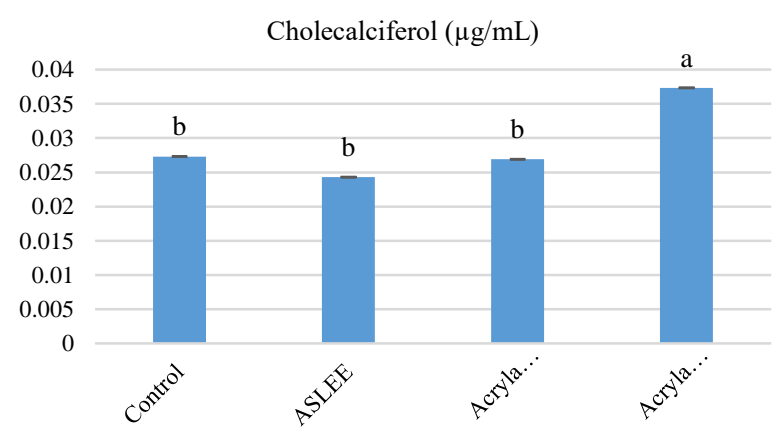

Figure 3. Comparison of cholecalciferol values between groups
Retinol and $\alpha$-tocopherol levels were determined as highest in the acrylamide group. There was no significant difference between the control and ASLEE groups in terms of retinol and $\alpha$-tocopherol levels. Cholecalciferol level was significantly higher in acrylamide + ASLEE group compared to the other three groups. However, there was no significant difference in terms of cholecalciferol levels between acrylamide, control and ASLEE groups. Detailed results regarding retinol, $\alpha$-tocopherol and cholecalciferol are presented in Figure 1, Figure 2 and Figure 3. Different letters $(\mathrm{a}, \mathrm{b})$ indicate significant inter-group differences $(\mathrm{P}<0.05)$.

\section{Discussion}

It is known that plant extracts are used in many studies and they have therapeutic power due to some features. In our study, acrylamide, which is reveal after carbohydraterich foods were cooked at high temperatures, is used. Also, ASLEE also known as Sirmo, is the basis of our study.

Although the serum estradiol values in the current study were partially lower in the acrylamide groups compared to other groups, there was no significant difference between the groups $(\mathrm{P}>0.05)$. This result is compatible with previous study results (Hamdy et al., 2017, Wei et al., 2014). Wei et al. (2014) also reported that when they administered acrylamide orally for 30 days, it significantly reduced the number of corpora lutea, body weights and organ weights. Our conclusion regarding estrodiol differ from the result of Mannaa et al. (2006). Mannaa et al. (2006) reported that in the acrylamide group, the level of estradiol significantly decreased compared to the control group. This difference between the two studies can be attributed to the differences in study times and acrylamide doses.

In our study, serum progesterone values were found to be significantly lower in acrylamide-administrated groups than in the control group $(\mathrm{P}<0.001)$. In our study, it was determined that serum progesterone value was higher in Acrylamide + ASLEE group than acrylamide group. Also, Wei et al. (2014) reported that serum progesterone concentrations decreased significantly with increasing acrylamide doses in their studies $(\mathrm{P}<0.05)$. Mannaa et al. (2006) reported that the progesterone value in the acrylamide group was significantly lower than the control group. However, Hamdy et al. (2017) reported that, unlike our study, the value of progesterone did not differ significantly between groups.

LH and FSH values were highest in the ASLEE group and lowest in the acrylamide group. Significant increase in serum LH and FSH values in Acrylamide + ASLEE group compared to acrylamide group shows the effect of ASLEE on $\mathrm{LH}$ and FSH. After the literature review, it was 
determined that $\mathrm{LH}$ and FSH parameters were not evaluated in either acrylamide or ASLEE studies. For this reason, the findings we obtained regarding $\mathrm{LH}$ and $\mathrm{FSH}$ in our study will remain as significant data.

In our study, we applied Acrylamide and ASLEE to rats and evaluated the levels of retinol, $\alpha$-tocopherol and cholecalciferol. To date, no studies on these parameters have been performed in any living creature administrated Acrylamide and ASLEE. Therefore, we have no chance to compare our data. In the current study, retinol and $\alpha$ tocopherol levels were found to be highest in the acrylamide group. There was no significant difference between retinol and $\alpha$-tocopherol levels in the control and ASLEE groups. While it was determined that cholecalciferol level was significantly higher in Acrylamide + ASLEE group than the other three groups, there was no significant difference between these three groups.

\section{Conclusion}

As a result, with the current study, retinol, $\alpha$-tocopherol and cholecalciferol levels, and LH and FSH levels were determined in rats administrated with acrylamide and ASLEE. We think that these results will shed light on future studies in this field and contribute to the literature.

\section{Conflict of interest}

There is no conflict of interest in this study.

\section{References}

Aamir M, Shazma N, Rukhsana A, Mehwish J, Habib A, Asifa B, Qurat-ul-Ain A, Baderqa tul A. 2016. Evaluation of Hypolipidemic Activity of Alliumschoenoprasum in Albino Rats. British Journal of Pharmaceutical Research 14(5):1-10.

Altinoz E, Turkoz Y. 2014. The protective role of NAcetylcysteine against acrylamide-1nduced genotoxicity and oxidati ve stress in rats. Gene Therapy and Molecular Biology. 16:35-43.

Çelik SE, Özyürek M, Altun M, Bektaşoğlu B, Güçlü K, Berker I. 2008. Antioxidant Capacities of Herbal Plants Used in the Manufacture of Van Herby Cheese: 'Otlu Peynir'. International Journal of Food Properties. 11(4):747-761.

Friedman MA, Dulak LH, Stedham MA. 1995. A lifetime oncogenicity study in rats with acrylamide. Fundamental and Applied Toxicology. 27:95-105.

Hamdy SM, Shabaan AM, Abdel Latif AKM, Abdel-Aziz AM, Amin AM. (2017). Protective effect of Hesperidin and Tiger nut against Acrylamide toxicity in female rats. Experimental and Toxicologic Pathology. 69(8):580-588.

Koçak Y, Oto G, Yücel UM, Yaşar S, Arıhan O. 2019. Karbon tetraklorür ile Oluşturulan Doku Hasarında Allium schoenoprasum L. Uygulamasının Karaciğer ve Böbrek Dokusunda Total Antioksidan ve Total Oksidan Düzeylerine Etkisi. Van Sağlık Bilimleri Dergisi. 12(3):1-10.
Mannaa F, Abdel-Wahhab MA, Ahmed HH, Park MH. 2006. Protective role of Panax ginseng extract standardized with ginsenoside $\mathrm{Rg} 3$ against acrylamide-induced neurotoxicity in rats. Journal of Applied Toxicology. 26(3):198-206.

Miller KW, Yang CS. 1985. An Isocratic High-Performance Liquid Chromatography Method for the Simultaneous Analysis of Plasma Retinol, $\alpha$-tocopherol and Various Carotenoids. Analytical Biochemistry. 145(1):21-26.

Mohammed FS, Şabik AE, Sevindik E, Pehlivan M, Sevindik M. 2020. Determination of Antioxidant and Oxidant Potentials of Thymbra spicata Collected from Duhok-Iraq. Turkish Journal of Agriculture-Food Science and Technology, 8(5): 1171-1173.

Mushtaq W, Baba H, Akata I, Sevindik M. 2020. Antioxidant Potential and Element Contents of Wild Edible Mushroom Suillus granulatus. Kahramanmaraş Sütçü İmam Üniversitesi Tarım ve Doğa Dergisi, 23(3): 592-595.

Parvu AE, Parvu M, Vlase L, Miclea P, Mot AC, Silagh1Dumitrescu R. 2014. Anti-inflammatory effects of Allum schoenoprasum L. Leaves. Journal of Physiology and Pharmacology. 65(2): 309-315

Reynolds SL, Judd HJ. 1984. Rapid Procedure for the Determination of Vitamins A and D in Fortified Skimmed Milk Powder Using High-Performance Liquid Chromatography. Analyst. 109(4):489-492.

Rommens CM, Yan H, Swords K, Richael C, Ye J. 2008. Low acrylamide French fries and potato chips. Plant Biotechnology Journal. 6(8):843-853.

Sevindik M, Akgul H, Pehlivan M, Selamoglu Z. 2017. Determination of therapeutic potential of Mentha longifolia ssp. longifolia. Fresen Environ Bull, 26(7): 4757-4763.

Sevindik M. 2020. Antioxidant and antimicrobial capacity of Lactifluus rugatus and its antiproliferative activity on A549 cells. Indian Journal of Traditional Knowledge (IJTK), 19(2): 423-427.

Shirshova TI, Beshlei V, Deryagina VP, Ryzhova NI. 2014. Thecomponentcomposition of steroidglycosidesextractedfromtheruits of Allum SchoenoprasumL. Andassessment of theireffects on thegrowth of transplanted tumorsinmice. Pharmaceutical Chemistry Journal. 48(5):28-31.

Singh V, Krishan P, Shri R. 2018. Antioxidant-mediated neuroprotection by Allium schoenoprasum $L$. leaf extract against ischemia reperfusion-induced cerebral injury in mice. Journal of Basic and Clinical Physiology and Pharmacology. 29(4), 403-410.

Viklund GA, Olsson KM, Sjöholm IM, Skog KI. 2008. Impact of harvest year on amino acids and sugars in potatoes and effect on acrylamide formation during frying. Journal of Agricultural and Food Chemistry. 56(15):6180-6184.

Zaspel BJ, Csallany S. 1983. Determination of Alpha-Tocopherol in Tissues and Plasma by High-Performance Liquid Chromatography. Analytical Biochemistry. 130(1):146-150.

Zeng Y, Li Y, Yang J, Pu X, Du J, Yang X, Yang T, Yang S. 2017. Therapeutic role of functional components in alliums for preventive chronic disease in human being. Evidence Based Complementary and Alternative Medicine. 2017:1-13.

Wang H, Huang P, Lie T, Li J, Hutz RJ, Li K, Shi F. 2010. Reproductive toxicity of acrylamide-treated male rats. Reproductive Toxicology. 29(2): 225-230.

Wei Q, Li J, Li X, Zhang L, Shi F. 2014. Reproductive toxicity in acrylamide-treated female mice. Reproductive Toxicology. 46: 121-128. 